\title{
ПРАВО ЕМБРІОНА/ПЛОДА НА ЖИТТЯ В КОНТЕКСТІ ГРОМАДСЬКОГО ЗДОРОВ'Я
}

\author{
Тернопільський національний медичний університет \\ імені І. Я. Горбачевського МОЗ України, м. Тернопіль, Україна
}

\begin{abstract}
Мета: дослідження права ембріона/плода на життя в контексті громадського здоров'я.
Матеріали і методи. У статті проведено аналіз чинних нормативно-правових актів. Застосовано такий комплекс методів: теоретичного аналізу, порівняння, обґрунтування, узагальнення, систематизації теоретичного та практичного матеріалу, фрормулювання і систематизації висновків.

Результати. Проаналізовано чинні нормативно-правові акти, що дають можливість систематизувати аргументацію різних підходів до розуміння та реалізації цього права. Запропоновано поділ аргументів на дві групи: ті, що підтверджують право ембріона/плода на життя, і ті, що обмежують (заперечують) це право. 3'ясовано, що Україна є прихильником позиції про те, що право на життя у людини виникає 3 моменту народження. Проте інші держави закріплюють право на життя ще ненародженої дитини шляхом уточнення правового припису 3 вказівкою, що право особи на життя виникає з моменту зачаття або ж внутрішньоутробного розвитку. Доведено, що репродуктивні права тісно пов'язані з найважливішим основним особистим правом людини - правом на життя. Взаємозв'язок права на життя з репродуктивними правами очевидний при розгляді правового режиму штучного переривання вагітності, при визначенні моменту виникнення життя та правового режиму плода чи ембріона. Здійснений аналіз міжнародних, регіональних та національних стандартів у сфері охорони здоров'я фрормує невирішену на сучасному етапі соціально-економічного, культурного і духовного розвитку суспільства суперечність з питань верховенства прав ненародженої дитини. Ця проблематика може бути усунена шляхом поступової гуманізації соціуму, реалізації принципу поваги до людської гідності.

Висновки. Доведено, що право на життя ембріона/плода людини в контексті громадського здоров'я забезпечує природне існування особи, має велике значення в системі прав і є основним досягненням світової спільноти. Обґрунтовано доцільність подальших наукових розробок із питань вдосконалення правового регулювання права ембріона/плода на життя на рівні національного законодавства.
\end{abstract}

КЛЮЧОВІ СЛОВА: громадське здоров'я; право на життя; правовий режим; ембріон; плід людини.

Право на життя є значущим елементом комплексу основних прав і свобод людини як до міжнародних, так і до національних нормативно-правових актів. Право на життя - невід'ємне право кожної людини, що охороняється законом.

До міжнародних стандартів з прав людини у сорері охорони здоров'я, що закріплюють право людини на життя, належать:

- Загальна декларація прав людини (ст. 3).

- Міжнародний пакт про громадянські та політичні права (ст. 6.1).

- Конвенція про права дитини (ст. 6.1).

До регіональних стандартів 3 прав людини у сорері охорони здоров'я, що закріплюють право людини на життя, належать:

- Афрриканська хартія прав людини і народів та відповідні протоколи (ст. 4).

- Європейська конвенція 3 прав людини і основоположних свобод (ст. 2.1).

- Американська декларація прав і обов'язків людини (ст. 1).

- Американська конвенція 3 прав людини (ст. 5.1).

Національне законодавство, що закріплює право особи на життя:

• Конституція України (ст. ст. 3, 21, 27, 64).

(c) Н. М. Калинюк, Т. Б. Кадобний, А. Т. Бучко, 2021
- Цивільний кодекс України (ст. 281).

- Закон України «Основи законодавства України про охорону здоров'я» (ст. ст. 50, 52) та ін.

Україна є прихильником позиції про те, що право на життя у людини виникає з моменту народження. Проте інші держави закріплюють право на життя ще ненародженої дитини шляхом уточнення правового припису 3 вказівкою, що право особи на життя виникає з моменту зачаття або ж внутрішньоутробного розвитку.

Основний Закон нашої держави у ст. 27 аксіоматично закріплює за кожною людиною їх невід'ємне право на життя та обов'язок країни захищати це право. Принагідно відзначити й те, що чинні міжнародні стандарти у сорері захисту прав людини гарантують будь-якій особі незалежно від її статі, віку, расової чи національної приналежності й соціального захисту її право на життя. До цих міжнародних нормативно-правових актів належать: Загальна декларація прав людини (1948р.) [2], Міжнародний пакт про громадянські та політичні права (1966р.) [3], Міжнародний пакт про соціальні, економічні та культурні права (1966р.) [5] та ін. Наведені правові приписи безапеляційно доводять, що право на життя є однією 3 найбільших та найважливіших цінностей будь-якого суспільства. Саме тому по- 
літика кожної держави світу спрямована на забезпечення якісного та повноцінного життя людини і громадянина, досягнення максимальних показників здоров'я і благополуччя населення. Одним із дієвих напрямків реалізації цієї державної політики в Україні варто вважати систему громадського здоров'я, активне становлення та розвиток якої спостерігають у сучасній світовій спільноті й в нашій державі зокрема. Так, 04 лютого 2021 р. Верховна Рада України прийняла Постанову «Про прийняття за основу проекту Закону України про систему громадського здоров'я» № 1207-IX. У пропонованому проекті закріплюється дефініційне розуміння громадського здоров'я як сорери знань та організованої діяльності суб'єктів щодо зміцнення здоров'я, запобігання хворобам, покращення якості та збільшення тривалості життя [6]. Означене підтверджує доцільність наукових досліджень у різних напрямках забезпечення реалізації особою її права на життя.

Актуальність теми обумовлюється підвищенням ролі та відповідальності держави, яка, відповідно до Конституції України, несе безпосередню відповідальність за визнання, дотримання і захист права на життя, як й інших конституційних прав. Питання дослідження права на життя людини неодноразово було предметом дослідження низки науковців, зокрема С. Дем'яноваПономаренко, Н. Калинюк, 3. Касса, В. Кравчук, А. Сальникова, Н. Семчук, С. Стеценко та ін. Разом 3 тим, очевидно, що право на життя, його забезпечення та захист не стали поки пріоритетним напрямком діяльності держави. Катастрофрічне загострення демографрічної ситуації в Україні свідчить про те, що юридичні гарантії права на життя, його захищеність багато в чому мають декларативний характер. Це зумовлює необхідність дослідження в контексті громадського здоров'я проблематики права на життя ще ненародженої дитини (ембріона, плода).

Мета роботи: дослідження права ембріона/плода на життя в контексті громадського здоров'я.

Матеріали і методи. У статті проведено аналіз чинних нормативно-правових актів. Застосовано такий комплекс методів: теоретичного аналізу, порівняння, обґрунтування, узагальнення, систематизації теоретичного та практичного матеріалу, орормулювання і систематизації висновків.

Результати дослідження та їх обговорення. Під ембріоном людини потрібно розуміти зародок людини на стадії розвитку до восьми тижнів (Закон України «Про заборону репродуктивного клонування людини» від 14.12.2004 р. № 2231-IV). Право ембріона людини на життя в контексті громадського здоров'я бере свій початок з питання виникнення права на життя.

До міжнародних та регіональних стандартів у сорері захисту прав людини в системі громадського здоров'я необхідно віднести: «Право кожного на життя охороняється законом. Нікого не може бути умисно позбавлено життя» (ст. 2 Конвенції про захист прав людини і осново- положних свобод, 1950 р.); «Кожна людина, де $б$ вона не перебувала, має право на визнання її правосуб'єктності» (ст. 16 Міжнародного пакту про громадянські та політичні права, 1966 р.; ст. 6 Загальної декларації прав людини, 1948 р.); «нтереси та благополуччя окремої людини превалюють над виключними інтересами усього суспільства або науки» (ст. 2 Конвенції про захист прав і гідності людини щодо застосування біології та медицини: Конвенція про права людини та біомедицину (Конвенція Ов'єдо, 1997 р.)) [11, 12]; «Право на життя захищається законом, в цілому - 3 моменту зачаття» (Американська конвенція про права людини, 1969 р.).

Разом 3 тим, хоч і національна правова доктрина гарантує кожній людині невід'ємне право на життя, однак Конституція України не вказує, 3 якого саме моменту виникає право на життя. У цьому контексті варто виділити три основні концепції: 1) ембріональна (право на життя виникає 3 моменту зачаття); 2) натусіальна (право на життя виникає з моменту народження); 3) концепція внутрішньоутробного розвитку (право на життя виникає 3 моменту фрормування нервової системи). Україна дотримується натусіальної концепції виникнення права на життя.

В Україні правовий статус людини не охоплює і статус ембріона. У міжнародному й національному праві відсутній єдиний підхід до розуміння права ембріона людини на життя і доволі поверхнево досліджено питання правового режиму ембріона. Охорона права та захист ембріона опосередковано здійснюється ч. 3 ст. 24, ч. 3 ст. 51 Конституції України, ст. ст. 49, 84, 110, 122, 123, 155 Сімейного кодексу України (2002р.), де закріплено принцип охорони дитинства та невід'ємного права на життя.

Інтереси вагітної жінки, в тому числі й її право на материнство, превалюють над інтересами ненародженої дитини. Національне законодавство закріплює право вагітної жінки на штучне переривання вагітності строком не більше 12 тижнів (ст. 50 Закону України «Основи законодавства України про охорону здоров'я» (1992р.), ч. 6 ст. 281 Цивільного кодексу України (1994р.)).

Ембріон - це зародок людини на стадії розвитку до восьми тижнів, він не є суб'єктом права. Плід - це внутрішньоутробний продукт зачаття, починаючи 3 повного 12-го тижня вагітності (3 84 доби від першого дня останнього нормального менструального циклу) до вигнання/вилучення 3 організму матері (Про затвердження Інструкції з визначення критеріїв перинатального періоду, живонародженості та мертвонародженості, Порядку реєстрації живонароджених і мертвонароджених, наказ Міністерства охорони здоров'я України від 29.03.2006 р. № 179).

У контексті репродуктивних прав жінки у правовідносинах із приводу штучного переривання вагітності законодавством позбавлено ембріона будь-якої правосуб'єктності. Суб'єктом права визнається лише вагітна жінка, яка зачала дитину та є її матір'ю (12 тижнів вагітності). 
Право ембріона людини на життя частково визначено в законодавстві, що регулює порядок застосування допоміжних репродуктивних технологій. Адже допускається імплантація ембріонів як допоміжна репродуктивна технологія в межах лікувальних програм. Ці програми включають: донацію гамет і ембріонів, кріоконсервування гамет і ембріонів. Однією 3 методик лікування визначено процеси запліднення і розвитку ембріонів до перенесення їх у матку пацієнтки, які здійснюються в умовах in vitro (у лабораторному посуді спеціального призначення поза живим організмом). Відповідно до п. 11.1. Порядку, ембріони визначено як «біологічний матеріал пацієнта/пацієнтів». Право розпоряджатися долею ембріона (стосовно можливих процедур і маніпуляцій щодо запліднення і культивування in vitro, ембріотранссреру в порожнину матки генетичної або сурогатної матері, кріоконсервації та зберігання, передавання для програм репродуктивних технологій іншим особам, редукції) має жінка (пацієнтка) - донор гамет. Таким чином, правовий режим ембріонів людини, створених in vitro, що перебувають поза живим організмом, вказує на їх повну залежність від згоди замовників репродуктивної програми, яка може бути відкликана до моменту перенесення ембріонів у живий організм.

Аналіз практики Європейського суду з прав людини щодо питання виникнення права на життя вказує на те, що чіткого підтвердження того, що ненароджена дитина має право на життя немає, однак має право на певну повагу, яка б забороняла вважати її власністю. У справі «Парілло проти Італії» (2015р.) висловлено правову позицію про те, що ембріони не можуть бути прирівняні до права власності.

Право на життя ембріона людини в контексті громадського здоров'я нерозривно пов'язано із репродуктивними правами вагітної жінки. Взаємозв'язок права на життя з репродуктивними правами очевидний при розгляді правового режиму штучного переривання вагітності, при визначенні моменту виникнення життя та правового режиму плода чи ембріона.

Суперечливість чинного законодавства і відсутність дієвих механізмів у системі громадського здоров'я 3 питань забезпечення збереження життя ще ненародженої дитини, що можливо розглядати як детермінанту покращення демографічної ситуації в державі, дає підстави для систематизації наукових підходів з питань права ембріона людини на життя. Пропонована систематизація полягає у поділі аргументів на дві групи: ті, що підтверджують право ембріона/плода на життя, і ті, що обмежують (заперечують) це право.

До першої групи варто віднести такі аргументи, що підтверджують право ембріона/плода людини на життя в контексті громадського здоров'я:

- обмеження законодавцем права вагітної жінки на штучне переривання вагітності лише за її бажанням (ч. 6 ст. 281 ЦК України);
- обмеження законодавцем можливості проведення операції із штучного переривання вагітності терміном 312 до 22 тижнів за умов наявності медичних або соціальних підстав, перелік яких затверджено Постановою Кабінету Міністрів України від 15.02.2006 р. № 144;

- визначення основних критеріїв життєздатності плода та його розвитку, що дають можливість медичним працівникам визначати правильну тактику ведення вагітності та пологів з метою збереження життя і здоров'я вагітної жінки та ще ненародженої дитини (на прикладі наказу МО3 України від 27.12.2006 р. № 900 «Про затвердження клінічного протоколу з акушерської допомоги «Дистрес плода при вагітності та під час пологів»);

- право на захист, право на повагу до гідності $€$ невід'ємними правами ще ненародженої дитини;

- реалізацію вагітною жінкою права на свободу і особисту недоторканність, права на сімейне і приватне життя, права на материнство варто розуміти як основні гарантії, що забезпечують права плода на життя.

На підтвердження висловленої позиції, принагідно навести приклад 3 практики ЄСПЛ, де у рішенні по справі «Д. проти Ірландії» (2006р.) заявниця вказувала на порушення державою її прав, передбачених ст. ст. 3, 8, 10, 13, 14 Європейської конвенції з прав людини. Підставою для порушення її прав вона вважала відсутність в Ірландії медичних послуг із переривання вагітності у випадку несумісних із життям аномалій плода. Суд дійшов висновку, що заявниця не вичерпала внутрішні засоби правового захисту щодо недопустимості абортів в Ірландії у разі несумісності з життям аномалії плода.

До другої групи необхідно віднести такі аргументи, що заперечують/обмежують право ембріона/плода на життя в контексті громадського здоров'я: відсутність застереження на законодавчому рівні про те, що право на життя виникає з моменту зачаття чи внутрішньоутробного розвитку; відсутність єдиної термінології у нормативно-правових актах (плід, плідне яйце, продукт зачаття); відсутність державної стратегії щодо охорони прав плода; інтереси вагітної жінки превалюють над інтересами ще ненародженої дитини.

Принагідним буде приклад 3 практики ЄСПЛ у справі «Боссо проти Італії» (2002р.). Чоловік оскаржував рішення його вагітної дружини про штучне переривання вагітності всупереч його бажання бути батьком, вважаючи, що було порушення ст. 2, 8 ЄКПЛ. Дослідивши питання про дотримання італійським законом справедливого балансу конфрліктних інтересів при захисті плода та жінки, суд прийняв рішення про відмову у задоволенні скарги. Суд висловив позицію у контексті розуміння ст. 8 ЄКПЛ про те, що будь-яка інтерпретація потенційних прав батька у разі, коли мама має намір здійснити аборт, повинна, насамперед, враховувати права жінки, оскільки питання вагітності, її збереження чи переривання стосується в першу чергу її. 


\section{Висновки}

Наведене дає підстави для фрормування висновку про те, що право на життя ембріона/плода людини в контексті громадського здоров'я забезпечує природне існування особи, має велике значення в системі прав і $€$ основним досягненням світової спільноти. Разом з тим, проблематика правового регулювання права ембріона/плода на життя потребує доопрацювання на рівні національного законодавства, що сприятиме ство- ренню механізмів захисту та відновленню права ембріона/плода людини на життя як основної детермінанти покращення демографічної ситуації в Україні.

Перспективи подальших досліджень полягають у розробці та імплементації правових документів задля створення механізмів захисту і відновлення права ембріона/плода людини на життя.

\section{Список літератури}

1. Права жінки у пологах та їх реалізація в Україні / А. Сальникова, О. Горбенко, Є. Кубах, А. Петровська. - К., 2018. -52 c.

2. Про прийняття за основу проекту Закону України про систему громадського здоров'я : Постанова Верховної Ради України від 04.02.2021 р. № 1207-ІХ [Електронний ресурс]. - Режим доступу : https://zakon.rada.gov.ua/laws/ show/1207-20\#Text.

3. Стеценко С. Г. Трансформація сорери охорони здоров'я України: роль медично-правових досліджень / С. Г. Стеценко // Актуальні проблеми медичного права: професійний погляд : матеріали Всеукраїнської наук.-практ. конфр., 29 лист. 2018 р., Київ. - Одеса : Фенікс, 2019. - С. 120-123.

4. Certain aspects of training future medical specialists on the basis of interdisciplinary integration / N. Kalyniuk, N. Maika, I. Rogalskyi [et al.] // International Journal of Management (IJM). - 2020. - Vol. 11, Iss. 9. - P. 939-946.

5. Convention on Human Rights and Biomedicine (ETS No.164). Council of Europe. (1997). Available at: https://www.coe. int/en/web/conventions/full-list/-/conventions/treaty/164.

6. Human Rights in Childbirth National Report: Ukraine. / S. Demianova-Ponomarenko, O. Vishkina, A. Salnykova [et al.] // 2016. - Available at: https://drive.google.com/open?id=0B5falgVXuVtzZEJINIdVZk1HVjA.

7. Kassa Z. Disrespectful and abusive behavior during childbirth and maternity care in Ethiopia: a systematic review and meta-analysis / Z. Kassa // BMC Res Notes. - 2019. - Vol. 12. - P. 83. Available at: https://doi.org/10.1186/s13104-0194118-2.

8. Realization of the right of pregnant women to health in the medical system of Ukraine: review article / M. Kravchuk, S. Lykhova, V. Kravchuk [et al.] // International Journal of Management (IJM). - 2020. - Vol. 11, Iss. 6. - P. 1658-1666.

9. Semchuk N. O. Pregnant woman as a special subject of medical relations. Die Wichtigsten Vektoren für die Entwicklung der Wissenschaft im Jahr 2020 / N. O. Semchuk // Lux. - 2020. - P. 59-60. Available at: https://doi.org/10.36074/24.01.2020. v2.18.

10. The United Nations. International Covenant on Civil and Political Rights (1966). URL : https://www.ohchr.org/en/ professionalinterest/pages/ccpr.aspx.

11. The United Nations. International Covenant on Social, Economic and Cultural Rights (1966). URL : https://www.ohchr. org/EN/Professionallnterest/Pages/CESCR.aspx.

12. The United Nations. Universal declaration of human rights (1948). URL : https://www.un.org/en/about-us/universaldeclaration-of-human-rights.

\section{References}

1. Salnykova, A., Horbenko, O., Kubakh, Ye., \& Petrovska, A. (2018). Prava zhinky u polohakh ta yikh realizatsiia v Ukraini. [Women's rights in childbirth and their implementation in Ukraine]. Kyiv [in Ukrainian].

2. (2021). Pro pryynyattya za osnovu proektu Zakonu Ukrayiny pro systemu hromadskoho zdorovya: Postanova; Verkhovna Rada Ukrayiny. № 1207-IKH vid 04.02.2021. [On adoption as a basis of the draft Law of Ukraine on the public health system: Resolution; Verkhovna Rada of Ukraine. No. 1207-IX dated 04.02.2021]. zakon.rada.gov.ua. - Retrieved from: https://zakon.rada.gov.ua/laws/show/1207-20\#Text [in Ukrainian].

3. Stetsenko, S.H. (2019). Transformatsiya sfery okhorony zdorovya Ukrayiny: rol medychno-pravovykh doslidzhen [Transformation of the healthcare sector of Ukraine: the role of medical and legal research]. Aktualni problemy medychnoho prava: profesiynyy pohlyad - Current Issues of Medical Law: a Professional View. Proceedings from All-Ukrainian scientificpractical. Conf, Kyyiv, (p. 120-123). Odesa: Feniks [in Ukrainian].

4. Kalyniuk, N., Maika, N., Rogalskyi, I., Kadobnyi, T., \& Lototska, O. (2020). Certain aspects of training future medical specialists on the basis of interdisciplinary integration. International Journal of Management (IJM), 11 (9), $939-946$.

5. (1997). Convention on Human Rights and Biomedicine (ETS No.164). Council of Europe. Retrieved from: https://www. coe.int/en/web/conventions/full-list/-/conventions/treaty/164.

6. Demianova-Ponomarenko, S., Vishkina, O., Salnykova, A., Shushaiilo, J., \& Dunayevska, A. (2016). Human Rights in Childbirth National Report: Ukraine. Retrieved from: https://drive.google.com/open?id=0B5falgVXuVtzZEJINIdVZk1HVjA. 7. Kassa, Z. (2019). Disrespectful and abusive behavior during childbirth and maternity care in Ethiopia: a systematic review and meta-analysis. BMC Res Notes, 12, 83. Retrieved from: https://doi.org/10.1186/s13104-019-4118-2.

8. Kravchuk, M., Lykhova, S., Kravchuk, V., Semchuk, N. \& Litvinova, I. (2020). Realization of the right of pregnant women to health in the medical system of Ukraine: review article. International Journal of Management (IJM). 11 (6), 1658-1666. 
9. Semchuk, N.O. (2020) Pregnant woman as a special subject of medical relations. Die Wichtigsten Vektoren für die Entwicklung der Wissenschaft im Jahr 2020. Lux, 20.01.2020, 59-60. Retrieved from: https://doi.org/10.36074/24.01.2020. v2.18.

10. The United Nations. International Covenant on Civil and Political Rights (1966). www.ohchr.org. - Retrieved from: https://www.ohchr.org/en/professionalinterest/pages/ccpr.aspx.

11. The United Nations. International Covenant on Social, Economic and Cultural Rights (1966). - www.ohchr.org. Retrieved from: https://www.ohchr.org/EN/Professionallnterest/Pages/CESCR.aspx.

12. The United Nations. Universal declaration of human rights (1948). - www.ohchr.org. - Retrieved from: https://www. un.org/en/about-us/universal-declaration-of-human-rights.

\section{THE RIGHT OF THE EMBRYO/FETUS TO LIFE IN THE CONTEXT OF PUBLIC HEALTH}

N. M. Kalyniuk, T. B. Kadobnyi, A. T. Buchko

I. Horbachevskyy Ternopil National Medical University, Ternopil, Ukraine

Purpose: to study the right of the embryo (fetus) to live in the context of public health.

Materials and Methods. The article analyzes the current regulations. Theoretical analysis, comparison, substantiation, generalization, systematization of theoretical and practical material, formulation and systematization of conclusions were used.

Results. The article analyzes the current regulations, which made it possible to systematize the argumentation of different approaches to understanding and implementing this right. The division of arguments into two groups is proposed: those that confirm the right of the embryo (fetus) to life and those that limit (deny) this right. It was found that Ukraine is a supporter of the position that the right to life arises from the moment of birth. However, other states enshrine the right to life of the unborn child by clarifying the legal provision stating that a person's right to life arises from the moment of conception or in utero. It is proved that reproductive rights are closely related to the most important basic personal human right - the right to life. The relationship between the right to life and reproductive rights is obvious when considering the legal regime of abortion, when determining the moment of life, when determining the legal regime of the fetus or embryo. The analysis of international, regional and national standards in the field of health care forms an unresolved conflict at the current stage of socioeconomic, cultural and spiritual development of society on the rule of the rights of the unborn child. This issue can be eliminated through the gradual humanization of society, the implementation of the principle of respect for human dignity.

Conclusions. It has been proven that the right to life of a human embryo (fetus) in the context of public health ensures the natural existence of a person, is of great importance in the system of rights and is a major achievement of the world community. The expediency of further scientific research on improving the legal regulation of the right of the embryo (fetus) to life at the level of national legislation is substantiated.

KEY WORDS: public health; right to life; legal regime; embryo; human fetus.

Відомості про авторів:

Рукопис надійшов до редакції 09.04.2021 p.

Калинюк Наталя Миколаївна - кандидат юридичних наук, доцент кафедри педагогіки вищої школи та суспільних дисциплін Тернопільського національного медичного університету імені І. Я. Горбачевського МОЗ України; тел.: +38(0352) 52-48-87.

Кадобний Тарас Богданович - кандидат фрілософрських наук, викладач кафедри педагогіки вищої школи та суспільних дисциплін Тернопільського національного медичного університету імені І. Я. Горбачевського МОЗ України; тел.: +38(0352) 52-48-87.

Бучко Андріана Тарасівна - студентка медичного фракультету Тернопільського національного медичного університету імені І. Я. Горбачевського МОЗ України; тел.: +38(0352) 52-48-87. 